\title{
How to evaluate the quality of remuneration policy? Evidence from the Polish banking sector
}

\section{AGNIESZKA SŁOMKA-GOŁȨBIOWSKA ${ }^{1}$ (]) and PIOTR URBANEK ${ }^{2 \star ~[] ~}$}

${ }^{1}$ Department of Comparative Studies, Warsaw School of Economics, Warsaw, Poland

${ }^{2}$ Department of Institutional Economics, University of Lodz, 41/43 Rewolucji 1905 St., 90-214, Lodz, Poland

Received: May 06, 2018 - Revised manuscript received: May 07, $2019 \bullet$ Accepted: August 01, 2019

(C) 2020 Akadémiai Kiadó, Budapest

\begin{abstract}
In our paper we use an institutional perspective to define the concept of the quality of remuneration policy. Traditional perspective focuses on pay-per-performance relationship between top executives' remuneration and companies' performance. This study is based on the assumption that the acquisition of normatively defined compensation practices and structures is more important for the successful organization than the practices which enhance efficiency defined on the basis of input (compensation) - output (company's performance) relationship. We examine the relationship between the quality of executive remuneration policy and corporate governance standards in banks with a controlling blockholder. Based on the sample of a hand-collected data on corporate governance characteristics, executive remuneration, and financial results of all public banks in Poland from 2005 to 2015, we find that the effective implementation of sound corporate governance practices should be rooted in the form of obligatory normative acts. Consistent with other studies we find a positive and statistically significant relationship between the corporate governance measures and the quality of remuneration policy. In particular, our study shows the significant role of two institutional factors positively determining the efficiency of incentive contracts: remuneration committees and institutional ownership. We also find that the banks controlled by foreign corporations, especially the US-UK-Ireland financial institutions, have a significantly more effective compensation policy than the banks controlled by domestic investors.
\end{abstract}

\section{KEYWORDS}

remuneration policy, banking sector, corporate governance

\section{JEL CLASSIFICATION INDICES}

G01, G32, G34, G38

\footnotetext{
*Corresponding author. E-mail: piotr.urbanek@uni.lodz.pl
} 


\section{INTRODUCTION}

Executive remuneration policy is a corporate governance mechanism. The way in which top executives are remunerated determines the way they run the business and the success of the organization. It has a significant impact on the operation of a company and the achievements of the goals and objectives posed to the company by all stakeholders. This is due to the key position occupied by top executives in the strategic and operational decision-making process. "Not only does it shape how executives behave, but it also helps determine what kinds of executives an organization attracts" (Jensen - Murphy 1990: 139). The term "remuneration policy" refers to the interlinked governance mechanisms which support the executive pay-setting process. It consists of the human resource management tools which specify the location of remuneration in the internal incentive structure, functions of remuneration, procedures for setting, differentiating and paying wages, disclosure rules, and the people and institutions involved in these processes.

The remuneration of top executives also arouses the lively interest of the public, especially at the time of market declines, crises and corporate scandals. There is a widespread belief that the level and growth of executive remuneration is often not related to economic performance of a company. It is emphasized that the benefits achieved by senior executives significantly exceed the benefits of other stakeholders, such as employees, shareholders, suppliers and customers. This is confirmed by the observations indicating the growing income inequality between executive pay and average wages in the economy. Already decades ago, a harsh conclusion was formulated in one of the works on the evaluation of remuneration policy for managers: "There is no rational basis for the compensation paid to top management" (Kerr - Betis 1987: 661).

The international financial crisis of 2008-2010 marked a significant milestone in the studies on remuneration policy in the banking sector. A comparison of research being conducted at the outbreak of the crisis with the research conducted at the time when the dysfunctionality of remuneration policy became revealed shows a significant reorientation on the part of the researchers dealing with this issue. Studies before the financial crisis do not treat institutions operating in the banking sector in any particular way. The theoretical basis of most research is the agency problem and the need for the construction of incentive contracts that would align the interests of executives and shareholders. Prior to the 2008/2009 crisis, the key issue was the pay-per-performance relationship (Barro - Barro 1990; Hubbard - Palia 1995; Demsetz Sainderberg 1999; Burghof - Hofman 2000; Ang et al. 2000; John - Yiming 2003; Doucouliagos et al. 2007; Cunat - Guadalupe 2009).

After the onset of the crisis, two research themes are especially often addressed. First, it is emphasized that the executives pay arrangements in the financial sector encouraged the adoption of a short-sighted perspective, without sufficient consideration of the long-term results. The structure of low base salaries and high bonus opportunities, paid in a combination of cash, stock and stock options, might have encouraged excessive risk-taking (Balachandran et al. 2010; Gregg et al. 2012; DeYoung et al. 2013; Vallascas - Hangendorff 2013). The second problem refers to the impact of the crisis on the benefits and losses borne by executives and shareholders, which was a consequence of phenomenon called "the Culture of Ownership." Banks' senior executives had significant stock ownership, which should have aligned their incentives with the long-term interests of shareholders (Fahlenbrach - Stulz 2009; Bebchuk et al. 2010; Bhagat - Bolton 2013). 
Our present paper fills this research gap by introducing an institutional perspective which can be used to define the concept of the quality of remuneration policy. This is a starting point to examine the relationship between the quality of executive remuneration policy and corporate governance standards in banks with a controlling blockholder in the banking sector in Poland. Taking into account that the board is responsible for setting executive remuneration policy, we examine the relationship between those board characteristics which are the determinants of remuneration policy quality. The latter is measured by an index based on information related to the variable components of executive pay, the diligence of the board remuneration committee and equity-based long-term incentive programs.

In our study we documented three main findings. The first one has significant implications for regulators. Our results indicate that the effective implementation of sound corporate governance practices by the Polish financial institutions should be rooted in the legislative system in the form of obligatory normative acts. Significant improvements in the quality of remuneration policy have only been observed since 2012, after the transposition of the European Community requirements into the Polish national law. However, it should also be emphasized that the level of quality still reaches only approximately $40-50 \%$ of the procedures required by law. It may show the weakness of the institutions responsible for the supervision of financial markets in terms of enforcement of the regulations. Secondly, consistent with other studies we find a positive and statistically significant relationship between the corporate governance measures and the quality of remuneration policy. In particular, our study shows the significant role of two institutional factors positively determining the efficiency of incentive contracts: remuneration committees and institutional ownership. We also find that the banks controlled by foreign corporations, especially the US-UKIreland financial institutions, have a significantly more effective compensation policy than the banks controlled by domestic investors. Consistent with the previous studies we documented that large banks and banks paying higher compensation to their CEOs have more efficient executive remuneration policies. Lastly, our study contributes to the literature on the role and effects of controlling shareholders, which is a common phenomenon in the European markets.

This study contributes to literature on remuneration policy in several ways. Firstly, the article applies an institutional perspective to the assessment of the quality of remuneration policy. The process-based, procedural perspective extends the two traditional approaches based on the perspectives of the agency and stakeholder theories. Secondly, our study investigates how effective the regulatory requirements on corporate governance are in terms of increasing the quality of executive remuneration policy. Thirdly, this study examines the efficiency of corporate governance standards in banks with a more concentrated ownership structure than in the US or the UK, where generally firms are more widely-held than in the continental Europe.

The paper is organized as follows. Section 2 describes research perspectives which can be used to assess the quality of remuneration policy. Section 3 presents institutional background related to the evaluation of executive remuneration quality. Section 4 provides a review of the literature and develops the hypotheses. The data and methodology are described in Section 5. Section 6 presents our findings from empirical tests. The last section offers conclusions.

\section{REMUNERATION POLICY QUALITY - RESEARCH PERSPECTIVES}

The criticisms of the practices associated with banks' executive pay give rise to a natural question: What is meant by an effective pay contract? Efficient remuneration policy should be in 
line with the business strategy, objectives, values and long-term interests of the institution. In order to make a practical assessment of the executive remuneration policy, the policy should be operationalized in such a way that would allow for verification of its quality and efficiency. The starting point for such assessments may involve specification of the model describing the process for establishing pay.

The decision taken by a company's board concerning the rules for determining the remuneration policy for management consists of three elements (Baker et al. 1988): the level, the functional form, and the composition of the remuneration package. The term "functional form" should be understood as the relationships existing between the remuneration, the criteria for its establishment and the method of determining the criteria. The composition of the remuneration package determines the amount, form and timing in which it is paid out, broken down into short-term and long-term, fixed and variable, and cash and non-cash components.

The functional form of remuneration and composition of the package comprise the process of determining remuneration (Bender - Porter 2001). It can be presented by a sequential model composed of two stages (Fig. 1). In the first stage, the company's board determines the general framework of the remuneration policy on the basis of inputs to the process, which include information about the economic environment of the company, the inside-organizational factors, and formal and legal regulations. In the second stage, the principles of this policy are translated into remuneration packages for individual officers. The output of the process is individually determined incentive packages, specifying the level, form and timing of remuneration paid to the top management of the company.

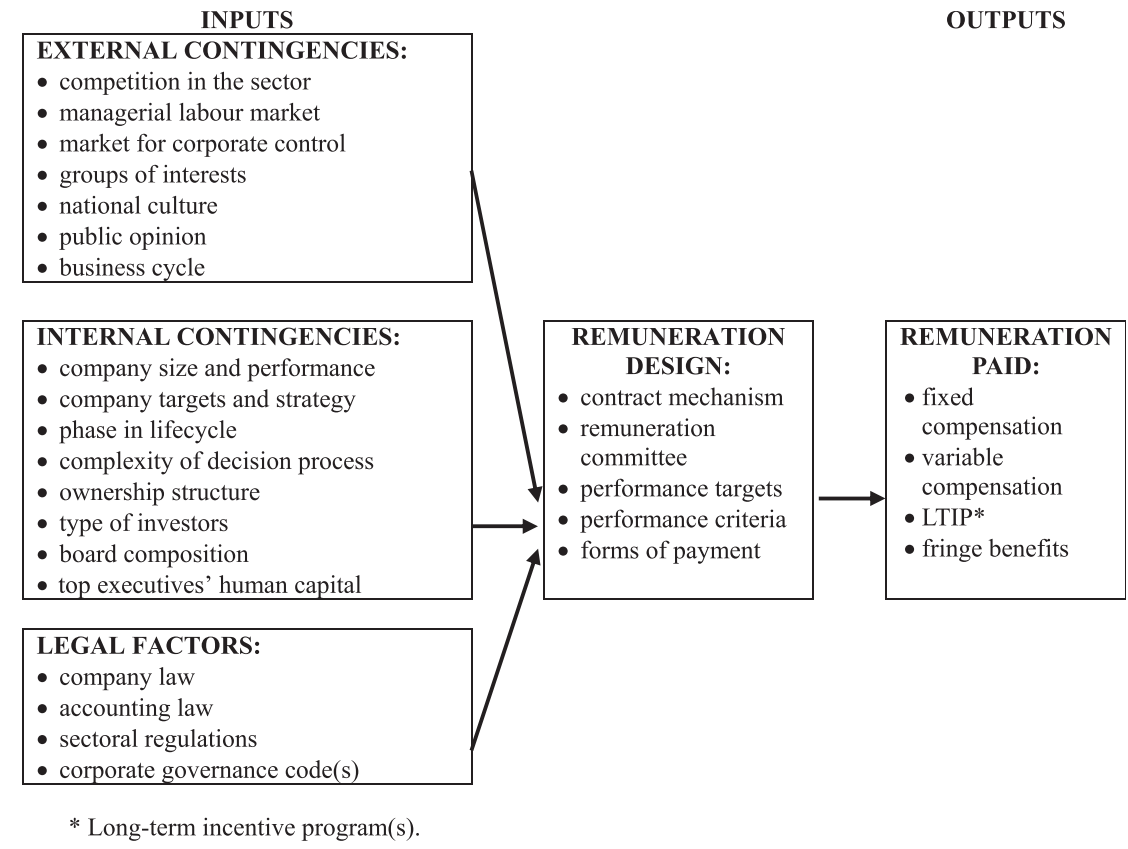

Fig.1. Process model of remuneration policy 
The process-based model of remuneration policy provides an indication of two alternative approaches to the assessment of the quality of the pay-setting process, referring to the theoretical research perspectives related to the agency and stakeholder theories. As Gordon, 2006: 106) argues "...the more general point is that executive compensation operates in at least two different worlds: one that focuses on maximizing shareholder value, the other that responds to concerns about the social implications of wealth and power."

The first approach is based on an assessment of the effectiveness of the remuneration policy pursued from the point of view of gains and losses achieved and borne by the managers and shareholders. This follows the assumption that the key resource used by the corporation is capital provided by the shareholders, and the primary objective of the corporation is to maximize the benefits of shareholders. Compensation arrangements are presumed to be shaped by market forces, which push toward shareholder value maximization (Bebchuk - Fried 2003). An effective executive remuneration policy within the context of the principal-agent framework means linking the amount of remuneration with benefits that a corporation may provide to shareholders.

An alternative approach accentuates corporate accountability based on the existence of a specific contract between the company and society. "The essence of the contract between society and business is that companies shall not pursue their immediate profit objectives at the expense of the longer-term interests of the community" (Cadbury 2002: 160-161). This can be described with reference to the stakeholder theory perspective, which perceives the corporation as a coalition of different groups of partners. The stakeholder theory scholars argue that the firm should not only focus on shareholders' interests but should aim to serve all non-shareholder stakeholders (Freeman 1984). This approach extends the list of standards which should be employed to ensure a high-quality executive compensation policy. The standards of this policy should take into account the interests of many parties associated with the operation of the corporation in order to achieve a balance between conflicting stakeholders' objectives.

A common feature of these two research perspectives used to assess the quality of the executive remuneration policy is that they focus on the level and determinants of remuneration. In the agency theory perspective, it is crucial to maintain the pay-per-performance relationship. In the stakeholder theory perspective instead of the one objective - shareholder value maximization - we have a bundle of objectives reflecting the expectations of different groups of stakeholders. Jensen Murphy (1990: 138) comment that "the relentless focus on how much CEOs are paid diverts public attention from the real problem - how CEOs are paid."

We propose a third alternative approach. As Tosi and Gomez-Mejia (1989: 18) wrote: "All things considered, overreliance on archival data that treats the executive process as a black box has led us into a blind alley. . . a more fruitful avenue to pursue in understanding executive pay issues is to focus more on the process and less on the observed objective measures." This may explain the fact that different studies on remuneration policy use "different methods of data collection, different statistical techniques, different samples, and differences in how the construct of interest have been operationalized" (Tosi et al. 2000: 305), leading to a radically different conclusion. "Part of the confusion in prior research on CEO pay may be attributed to the fact that investigators often fail to distinguish the process used to reward or punish the executives" (Gomez-Mejia - Wiseman 1997: 292). Therefore attention "should be directed to the process through which the pay contract is negotiated and to how optimum incentive contracts can be supported" (Ferrarini et al. 2010: 81).

The process-based approach to assessment of the quality of remuneration policy has its theoretical justification in the institutional and legitimacy theory. As Redmond (2004: 179) writes "institutional 
Table 1. Evaluation of compensation policy - research perspectives

\begin{tabular}{|c|c|c|c|}
\hline $\begin{array}{c}\text { Theoretical } \\
\text { framework }\end{array}$ & Agency theory & Stakeholder theory & Procedural perspective \\
\hline $\begin{array}{c}\text { Nature of the } \\
\text { firm }\end{array}$ & $\begin{array}{c}\text { A nexus of contracts } \\
\text { voluntarily negotiated among } \\
\text { the rationally selfish and } \\
\text { individualist parties who join } \\
\text { the corporate enterprise }\end{array}$ & $\begin{array}{c}\text { Coalition of groups of } \\
\text { stakeholders with conflicting } \\
\text { interests }\end{array}$ & $\begin{array}{c}\text { Entity whose actions are } \\
\text { desirable, proper, or } \\
\text { appropriate within some } \\
\text { socially constructed system } \\
\text { of norms, values, beliefs } \\
\text { and definitions }\end{array}$ \\
\hline $\begin{array}{c}\text { Criterion of } \\
\text { evaluation }\end{array}$ & Pay-per-performance & $\begin{array}{c}\text { Achieving a balance between } \\
\text { conflicting objectives of } \\
\text { various stakeholder groups }\end{array}$ & $\begin{array}{c}\text { Performing in accordance } \\
\text { with socially accepted } \\
\text { standards of } \\
\text { professionalism }\end{array}$ \\
\hline
\end{tabular}

rationality .... requires two types of thinking, one which produces rule-following behaviours and one which produces purpose-seeking behaviours." A similar pattern of behaviour may be expressed within a framework of legitimization theory. "Legitimacy is a generalized perception or assumption that the actions of an entity are desirable, proper or appropriate within some socially constructed system of norms, values, beliefs and definitions" (Suchman 1995: 574). This means that organizations must be aware of the "socially constructed standards of quality and desirability as well as perform in accordance with accepted standards of professionalism" (Hearit 1995: 2).

Thus understood, institutional rationality and legitimacy impose expectations on decisions made and governance structures used in corporations. Whether a certain governance standard is accepted as rational, legitimate and ethical will depend on the specific procedures which are implemented within these standards. As Kim et al. (2012: 765) comment, "firms/managers have an incentive to be honest, trustworthy and ethical in their business processes, and thus, tend to adhere to a high standard of behaviour." In this context, a high quality of remuneration policy means both the use of legislative supervisory standards as well as compliance with the rules, which have not been provided by these norms, but are in line with the acceptable standards of social behaviour in the social environment as broadly understood (Table 1).

The assessment of remuneration policy using a procedural perspective focuses on the phenomena creating the functional form of this policy. In particular, it concerns the relationship between the basic and performance-related components of compensation, methods used to measure performance, determinants of performance targets, forms of payments, roles of individuals and institutions engaged in the process of setting compensation and transparency standards, etc.

\section{THE QUALITY OF REMUNERATION POLICY - INSTITUTIONAL BACKGROUND}

In this section, we discuss the study's regulatory context. It is a widely-held opinion that the financial crisis revealed the poorly designed executive pay policies in the banking sector. 
Inefficient remuneration structures encouraged managers to take excessive risks and focus on short-term results of the bank. In response to such phenomena, numerous legislative initiatives have been taken to strengthen the existing standards and create new ones reforming the executive pay structures through the remuneration governance mechanisms (Ferrarini et al. 2010; Murphy 2011). These financial-crisis-related reform movements have been undertaken by numerous international institutions, including the Financial Stability Board, the Committee of European Banking Supervisor, the European Banking Authority, the European Commission, the European Parliament and national regulators. Initially, the transmission channel of the standards governing the business practices of the financial sector in most highly developed countries, including the EU Member States, involved the best practices recommendations included in the Corporate Governance Codes. This sequence resulted from the fact that such regulations are much more flexible and the implementation of new solutions does not require laborious parliamentary legislative procedures. In this way it is possible to gradually attain effective governance standards of good business practices, tailored to specific companies' needs, which can then become the starting point for creating an effective legal framework. On the other hand, however, the non-binding nature of the corporate governance framework, based generally on a "comply or explain" mechanism, did not sufficiently facilitate the effective implementation of sound corporate governance practices by financial institutions. Thus, in subsequent years they were transferred to the legislative system, in the form of obligatory normative acts.

There are two basic aspects of compensation policy which have been the subject of numerous regulations, both national and supranational. The first involves improving the disclosure of compensation transparency. The latter, referring directly to the remuneration policy quality, involves pay design, procedures for setting remuneration, and its level and structure.

There are three groups of issues which have been of particular interest in the reforms of the executive compensation policy procedures. They refer to variable remuneration, the functions of remuneration committees and long-term incentive plans.

Efficient, incentive-based executive pay contracts depend, first of all, on variable remuneration. Such performance-related awards allow firms to manage costs dynamically, adjusting the level of remuneration awarded by managers each year to performance. But bonus plans can also provide incentives to take risks through two channels: asymmetric rewards and penalties, and performance measures that reward risky behaviour (Murphy 2012). Due to the dysfunctionality in this regard, remuneration policy has been identified as one of the main causes of the financial crisis. The effective framework for variable remuneration depends on (EBA 2015: 12):

- The performance objectives for the institution, business areas and staff;

- The methods for the measurement of performance, including the performance criteria;

- The structure of variable remuneration, including where applicable the instruments in which parts of the variable remuneration are awarded;

- The ex ante and ex post risk-adjustment measures of the variable remuneration.

The assessment of the performance-based component of remuneration should be based on long-term performance and take into account both the current and future risks associated with the performance. A multidimensional approach to performance measurement should be in accord with both financial criteria as well as with non-financial factors, such as "skills acquired, personal development, compliance with the institution's systems and controls, commitment to the business strategies and its major policies and contribution to the performance of the team" 
(CBES 2009: 4). Unethical or non-compliant behaviour cannot be compensated for by good financial performance. The actual payment of the variable components of remuneration should be spread over a period which takes into account the underlying business cycle of the institution and its business risks. Recommended risk-adjustment mechanisms should combine the malus and claw back arrangements. They should lead to reduction of the variable components of remuneration where appropriate. Claw back should, in particular, be applied when an identified staff member contributed substantially to significant financial losses.

The second group of recommendations emphasizes the role of the remuneration committee. A financial institution's oversight regarding the remuneration policies, pay and bonuses should be located in a centralized decision-making entity, which will be better able to align individual remuneration packages with the company's overall performance. Institutions that are significant in terms of their size, internal organization, and the nature, scope and the complexity of their activities must establish a remuneration committee. Its main task is the preparation of decisions on remuneration, in particular regarding the remuneration of the members of the management body in its management function. The remuneration committee should be composed of members of the supervisory function and not perform executive functions. The chair and the majority of members of the remuneration committee should be independent. Members of the committee should have, collectively, appropriate knowledge, expertise and professional experience concerning remuneration policies and practices, risk management and control activities, especially with regard to the mechanisms for aligning the remuneration structure to institutions' risk and capital profiles.

Incentive compensation consists of bonuses and grants of company stock and options. Performance-based incentive pay should include deferred equity-based payment, which is valuable in motivating executives to increase their efficiency. This aligns the interests of executives with the long-term interests of the institutions, shareholders and non-shareholder constituencies. Therefore, a substantial portion, in any event of at least $40 \%$, of the variable remuneration component should be deferred over a period not less than three to five years. In the case of a particularly high variable remuneration component, at least $60 \%$ of the amount should be deferred (EP 2013, article 94). It should consist of a balance of shares and/or equivalent ownership interests, subject to the legal structure of the institution concerned. Such deferred equity awards should therefore be linked to future performance measures within a reasonable time horizon and should be risk-adjusted.

The implementation of an efficient, incentive-based executive remuneration policy into the Polish legislative system initially took the form of recommendations in the Corporate Governance Codes, applicable to all public companies. The institutions responsible for the supervision of financial markets in Poland did not recognize the need to cover the remuneration policies in banks by special regulations until 2011. The key step to a better quality remuneration policy in the Polish banking sector was the transposition of the European Community requirements into the national law and best practice guidelines.

The amended Banking Law adjusted the Polish legislation on the financial sector to international regulations related to remuneration policy. Apart from the Banking Law regulations relating to the remuneration policies in the banking sector, the Polish Financial Supervision Authority also deals with this issue. In response to the EU regulations relating to remuneration policy in the banking sector, two resolutions regulating the two above-indicated issues were published in October 2011: (1) procedures for determining remuneration; and (2) its 
transparency. In 2014, the Polish Financial Supervision Authority issued "Corporate Governance Principles for supervised institutions," which contained a separate chapter devoted to remuneration policy including the provisions on the remuneration of top management. Transposition of the provisions of the CRD IV Directive took place in November 2015. It referred to the structure of a bank's management remuneration, and required reducing the amount of variable remuneration of persons covered by the remuneration policy, as a percentage of net revenues, where its amount makes it difficult to meet the requirements for equity.

The above-described three pillars of executive compensation reforms in the financial sector constitute the basis for the construction, in our study, of a remuneration policy quality index, consisting of three sub-indices related to information on:

1. Variable components of compensation packages;

2. Remuneration committees; and

3. Long-term incentive plans.

For each of the sub-indices information was collected on various aspects of the executive remuneration policy in each of these areas. The selection of 12 items included in the executive remuneration policy quality checklist with respect to first sub-index was guided by the CRD III and CRD IV rules, by the amended Banking Act and by the Polish Financial Supervisory Authority's Resolutions (a maximum score in the first index is 17). The second sub-index contains nine norms related to the structure and functions of the remuneration committee, enforcing the provisions of CRD III, which have not been completely transferred into the Polish law (a maximum score of the second index is 14). The last sub-index contains ten attributes, which can be the basis for assessing the scale of the use of equity-based long-term incentive plans (with a maximum score of 17). Appendix 1 presents the detailed questions used to assess the quality of executive remuneration policy in the banks in Poland.

All variables used to construct the sub-indices, as proxies for compensation policy quality, are stimulants, so that a higher index value means a higher quality in this area of remuneration policy, which is described by the given index. We assume that each of the sub-indices has the same effect on the level of quality of a remuneration, hence we scale each sub-indices' score for each bank by the maximum available score for the given index and base our analysis on the relative measures. The relative value of the sub-indices for each bank is in the range of $(0,1)$. Because the number of variables forming sub-indices and maximum index values vary, we sum up all relative sub-indices to reach the aggregate executive remuneration policy quality index, according to the formula:

$$
A I Q j=\sum_{k=1}^{3} \frac{Q i, j}{\max Q i}
$$

where:

$A I Q j$ - value of aggregate executive remuneration policy quality index for bank $j$,

$Q i, j$ - value of sub-index $i$ for bank $j$,

max $Q i$ - the maximum available score of the sub-index $i$.

The AIQj index ranges from 0 to 3 . The larger is the AIQj, the higher is the quality of executive remuneration policy for a given bank. 


\section{LITERATURE REVIEW AND HYPOTHESES DEVELOPMENT}

Different studies of corporate governance clearly demonstrated that countries differ in terms of legal and institutional contexts (Shleifer - Vishny 1996). This may be a basis to extract three basic corporate governance models: the Anglo-Saxon model, the Continental model and the Japanese model. There are fundamental features in each national corporate governance system which position this system in a specific corporate governance model (Vives 2000): ownership structure and types of shareholders, governance institutions, the role of the market for corporate control and the rights of shareholders.

The main features of the Anglo-Saxon corporate governance model are an outsider system of corporate control and dispersed ownership structure. Shares are in the hands of a large number of small individual or institutional shareholders. They do not engage in the monitoring processes, and corporations are controlled by the top management. Companies apply a one-tier board and the appointment of board members may be manipulated by the top management through a proxy fight. Capital market is well developed and the market for corporate control is an important external mechanism of corporate governance because it disciplines managers and reduces managerial opportunism. Conflicts of interest between small and weak owners and strong managers are the most important problem which should be solved by the corporate governance mechanisms. The key characteristics of the Continental model are an insider system of corporate control and high ownership concentration. A small number of large shareholders can control the most important strategic decisions and protect their interests. Companies operating within the Continental model usually have a two-tier board, which is composed of the supervisory board and management board. The market for corporate control is not very active, therefore hostile takeovers at the governance mechanism are rare. Banking system plays the most important role in financing companies. Due to such ownership structure and the poor institutional protection of the minority shareholders, this model may lead to the occurrence of the principal - principal conflict between the majority and minority shareholders. Therefore, the most important challenge for the corporate governance mechanisms is to protect the interests of the minority shareholders. The corporate governance model in Japan resembles the American one in terms of the legal form of corporation. The United States had a strong influence on the development of the Japanese legal system and the structure of its institutions after the Second World War. On the other hand, the Japanese model combines original features related to the history, evolution, and national, economic and social conditions (Passador 2017). The ownership structure in Japan is highly concentrated with cross-shareholding among management-friendly "stable" corporate shareholders. In theory, the rights of shareholders in Japan are strong, because they can nominate directors directly, and also management remuneration must be decided at general meetings of shareholders. In practice, shareholders do not have much influence, due to the structure of boards of directors with the overwhelming majority of insider directors. Nominations of board members are controlled by the company's CEO. Such strong position of top executives and also the presence of controlling shareholders lead to both types of conflicts of interests, which occur both in the Anglo-Saxon and the Continental models of corporate governance.

Differences in national characteristics of the corporate governance mechanisms lead to different fundamental problems which have to be solved by sound governance practices. A common feature of all corporate governance environments is a key role of top executive's remuneration policy in solving such problems. Effective pay setting practices can protect interests of weak shareholders regardless of who tries to violate them, strong managers in the 
Anglo-Saxon model or majority shareholders in the Continental or Japanese models. In this context it seems interesting to point out the key determinants of effective remuneration policy.

There is a research gap when it comes to the analysis of the determinants of the quality of executive remuneration policy. Most literature about executive compensation examines determinants of the level and the structure of remuneration. There are also studies that analyse the relationship between corporate governance and the transparency of executive compensation disclosure (Coulton et al. 2001; Clarkson et al. 2005; Muslu 2007; Ben-Amar - Zeghal 2011; Chung et al. 2015; Katmon Al Farooque 2017). However, research is very limited on the issue of the executive remuneration policy quality, including that of the financial sector institutions. The studies presented in this article thus provide one of the first attempts to examine the impact of corporate governance standards on the quality of the executive remuneration policy in banks. While presenting the results of empirical research, in the absence of studies directly referring to determinants of the quality of the remuneration policy we indicate the potential factors affecting the transparency of the policy.

This paper tests five interrelated hypotheses:

$\mathrm{H1}$ : The quality of the executive remuneration policy is negatively associated with the size of the board.

H2: The quality of the executive remuneration policy is positively associated with board independence.

H3: The quality of the executive remuneration policy is positively associated with the frequency of remuneration committee meetings.

H4: The quality of the executive remuneration policy is positively associated with the ownership concentration.

H5: Greater involvement of institutional investors in the shareholder structure of banks leads to improved quality of the remuneration policy.

\section{METHODOLOGY}

\subsection{Data and sample}

We used the sample of banks whose shares were publicly traded on the Warsaw Stock Exchange between 2005 and 2015. The number of banks used for analysis differs throughout the years, from 13 in years 2005, 2006, 2014, 2015, to 15 in 2012. Our sample includes 150 observations in an unbalanced micro-panel (Green 2003). The data on corporate governance characteristics, executive remuneration and financial results were hand-collected from bank's annual, corporate governance and capital adequacy reports, as well as minutes from the bank's general meetings. The data source for the value of equity in the hands of institutional investors is the Polish Financial Supervisory Authority.

\subsection{Model specification}

The method by which we examine the determinants of the quality of remuneration policy is the regression model, with the aggregate executive remuneration policy quality index (AIQ) as the 
Table 2. Description of independent variables

\begin{tabular}{|c|c|c|}
\hline Independent variables & Measurement & $\begin{array}{l}\text { Expected } \\
\text { sign }\end{array}$ \\
\hline Board size (BSIZE) & Number of board members & - \\
\hline Board independence (BIND) & The share of independent board members & + \\
\hline $\begin{array}{l}\text { Frequency of remuneration committee } \\
\text { meetings (RCOM) }\end{array}$ & Number of remuneration committee meetings & + \\
\hline Women on board (BDIV) & The share of women in supervisory board & + \\
\hline Ownership concentration (OWNC) & Equity stakes in the hand of a dominant shareholder & + \\
\hline Pension funds ownership (PFOWN) & $\begin{array}{l}\text { Accumulated equity stakes in the hands of private } \\
\text { pension funds }\end{array}$ & + \\
\hline Southern Europe (SEUR) & $\begin{array}{l}\text { Dummy variable equals } 1 \text { if the largest shareholder } \\
\text { of a bank comes from Southern European country }\end{array}$ & $?$ \\
\hline Northern Europe (NEUR) & $\begin{array}{l}\text { Dummy variable equals } 1 \text { if the largest shareholder } \\
\text { of a bank comes from Northern European country }\end{array}$ & $?$ \\
\hline US-UK-Ireland (USUKI) & $\begin{array}{c}\text { Dummy variable equals } 1 \text { if the largest shareholder } \\
\text { of a bank comes from one of the following countries: } \\
\text { US, UK or Ireland }\end{array}$ & + \\
\hline Poland (POL) & $\begin{array}{c}\text { Dummy variable equals } 1 \text { if the largest shareholder } \\
\text { of a bank comes from Poland }\end{array}$ & - \\
\hline Regulations (REG) & Dummy variable equals 1 for years after 2011 & + \\
\hline CEO's annual remuneration (CEOR) & CEO's annual remuneration in thousands of PLN & + \\
\hline Bank size - assets (ASSET) & Assets in millions of PLN & + \\
\hline $\mathrm{ROE}_{\mathrm{t}}(\mathrm{ROE})$ & Return on equity, $\%$ & + \\
\hline Leverage (LEV) & Total debt/total assets, $\%$ & + \\
\hline Investment opportunity (INVOP) & $\begin{array}{l}\text { Ratio of the market value of equity plus the book } \\
\text { value of debt to the book value of assets }\end{array}$ & $?$ \\
\hline
\end{tabular}

dependent variable and a set of a bank's corporate governance measures and various controls as the independent variables (Table 2).

We specify and estimate the following model for the determination of compensation policy quality:

$$
\begin{aligned}
\text { AIQ }_{i, \mathrm{t}} & =\alpha_{0}+\alpha_{1} \text { BSIZE }_{\mathrm{i}, \mathrm{t}}+\alpha_{2} \text { BIND }_{\mathrm{i}, \mathrm{t}}+\alpha_{3} \mathrm{RCOM}_{\mathrm{i}, \mathrm{t}}+\alpha_{4} \mathrm{BDIV}_{\mathrm{i}, \mathrm{t}}+\alpha_{5} \mathrm{OWNC}_{\mathrm{i}, \mathrm{t}} \\
& +\alpha_{6} \mathrm{PFUND}_{\mathrm{i}, \mathrm{t}}+\alpha_{7} \mathrm{SOUE}_{\mathrm{i}, \mathrm{t}}+\alpha_{8} \mathrm{NORE}_{\mathrm{i}, \mathrm{t}}+\alpha_{9} \mathrm{USUK}_{\mathrm{i}, \mathrm{t}}+\alpha_{10} \mathrm{POL}_{\mathrm{i}, \mathrm{t}}+\alpha_{11} \mathrm{REG}_{\mathrm{i}, \mathrm{t}} \\
& +\alpha_{12} \mathrm{CEOR}_{\mathrm{i}, \mathrm{t}}+\alpha_{13} \text { SIZE }_{\mathrm{i}, \mathrm{t}}+\alpha_{14} \mathrm{ROE}_{\mathrm{i}, \mathrm{t}}+\alpha_{15} \mathrm{LEV}_{\mathrm{i}, \mathrm{t}}+\alpha_{16} \mathrm{INVOP}_{\mathrm{i}, \mathrm{t}}+\varepsilon_{\mathrm{i}, \mathrm{t}}
\end{aligned}
$$

The first group of independent variables refers to corporate governance measures such as: supervisory board size (BSIZE), independence (BIND) and its remuneration committee's diligence 
(RCOM). We also add gender diversity (BDIV) as another board's characteristic, according to the studies reporting that females should improve company monitoring (Adams - Ferreira 2009; Loukil - Yousfi 2016). Given the specificity of the Polish corporate governance of banks with a highly concentrated ownership structure, we add two other corporate governance measures: the largest shareholder stake (OWNC) and accumulated stake in the hands of private pension funds (PFUND), which are the most significant institutional minority shareholders. We also distinguish four dummy variables that indicate the identity of a dominant shareholder. They equal one if the bank's ultimate parent company is located in, respectively, Southern Europe (SOUE), Northern Europe (NORE), US-UK-Ireland (USUK) or in Poland (POL). Otherwise they equal zero. We expect that among the foreign-owned banks, those controlled by the investors from the US, UK and Ireland will have a higher level of compensation quality than other banks. An additional dummy variable (REG) reflects changes which have been introduced after 2011, imposing new regulations in the area of remuneration policy in the Polish banking sector.

Our model includes several control variables. We control for the level of bank's executive remuneration (CEOR). Particular attention is paid to corporations whose top executives are at the top of the rankings of best-paid managers. This may attract closer investor scrutiny and increases the risk of litigation (Muslu 2007). In this situation one can expect that such corporations will try to pursue an effective remuneration policy in order to justify, explain and legitimize the fact that their senior executives receive pay significantly higher than those in the managerial labour market. This is to protect the reputation of the company's board and executives against social disapproval. Another factor leading to improved efficiency is explained on the basis of the theory of political costs. By providing public access to detailed information, highly paid managers seek to minimize the political costs, anticipating potential sanctions as results of the political scrutiny which might arise if the remuneration policy was less effective.

We also control for possible links between bank size, measured as the natural logarithm of the book value of total assets (SIZE). A larger size should increase the effectiveness of the procedures used in the framework of the remuneration policy. A number of arguments supports this view. The remuneration policy of large corporations is more complex, and a wider disclosure revealing the high quality of this policy may bring a number of benefits for the company. Large corporations are often under political pressure, which requires them to implement effective systems of executive compensation, which should include model solutions for other entities. This results in higher quality. This is consistent with prior studies, such as Coulton et al. (2001); Lang - Lundholm (1993); Eng - Mak (2003).

Furthermore, this study controls for bank's performance, measured as the return on equity (ROE); bank's leverage, measured as the ratio of the total debt to total assets (LEV); and investment opportunities, measured as the ratio of the market value to book value of assets (INVO). We expect that banks with better economic performance implement more efficient remuneration policy. We include leverage because highly leveraged companies typically have higher agency costs, and effective incentive contracts partly mitigate these costs (Clarkson et al. 2005).

\section{RESULTS}

\subsection{Descriptive statistics}

The mean (median) value of the aggregate index of executive's remuneration policy quality is $0.78(0.82)$, with a standard deviation of 0.52 , a minimum of 0 and maximum of 2.03 . For 
Table 3. Descriptive statistics

\begin{tabular}{|l|c|c|c|c|c|c|}
\hline & & Mean & Median & Std. Dev. & Min & Max \\
\hline $\begin{array}{l}\text { Aggregate index of executive' remuneration } \\
\text { policy quality }\end{array}$ & 1 & 0.78 & 0.82 & 0.52 & 0 & 2.03 \\
\hline Board size & 2 & 8.89 & 9.00 & 2.38 & 5.00 & 17.00 \\
\hline Board independence & 3 & 47.87 & 50.00 & 17.71 & 0.00 & 85.71 \\
\hline $\begin{array}{l}\text { Frequency of remuneration } \\
\text { committee meetings }\end{array}$ & 4 & 2.25 & 2.00 & 2.32 & 0.00 & 8.00 \\
\hline Women on board & 5 & 12.81 & 11.11 & 13.47 & 0.00 & 60.00 \\
\hline Ownership concentration & 6 & 71.72 & 75.00 & 17.88 & 19.97 & 100.00 \\
\hline Pension funds ownership & 7 & 9.36 & 7.64 & 8.29 & 0.00 & 30.49 \\
\hline Southern Europe & & 0.23 & 0.00 & 0.42 & 0 & 1 \\
\hline Northern Europe & & 0.37 & 0.00 & 0.48 & 0 & 1 \\
\hline US-UK-Ireland & & 0.17 & 0.00 & 0.37 & 0 & 1 \\
\hline Poland & 11 & 0.24 & 0.00 & 0.43 & 0 & 1 \\
\hline Regulations & 12 & 1.10 & 1.06 & 0.17 & 0.72 & 2.03 \\
\hline CEO's annual remuneration & 8 & 2,833 & 2,397 & 1,888 & 259 & 11,769 \\
\hline Bank size - assets & 9 & 57,372 & 41,332 & 50,788 & 1,965 & 266,940 \\
\hline R0E & 10 & 10.88 & 11.78 & 7.72 & -31.41 & 30.60 \\
\hline Leverage & 11.69 & 90.27 & 3.17 & 74.37 & 95.10 \\
\hline Investment opportunity & & 0.38 & 0.00 & 0.49 & 0 & 1 \\
\hline
\end{tabular}

corporate governance measures their mean and median values are close. The average size of the supervisory board is nine members, with a minimum of five and maximum of seventeen members. About half of them are independent. In our sample remuneration committees meet, on average, twice a year, with the maximum number of meetings being eight. Women rarely have representatives on the supervisory boards, and they constitute on average only about $12 \%$ of board members, with a maximum of $60 \%$. Publicly traded banks in Poland have a very concentrated ownership structure. The largest shareholder controls, on average, about $72 \%$ of votes at the general meeting. Private pension funds, as the most important minority shareholders, possess an accumulated equity stake of less than $10 \%$ of bank's shares. In 2012, domestic capital controlled four out of 15 banks, with the rest in the hands of controlling foreign investors, four from Southern, five from Northern Europe and two from the Anglo-Saxon countries (Table 3).

Our model includes variables indicating the economic determinants of the quality of remuneration policy. There is considerable diversity in the economic characteristics of the sample. The value of total assets of our sample banks ranges from 266,940 million PLN (77,000 
Table 4. Correlation matrix

\begin{tabular}{|l|c|c|c|c|c|c|c|c|c|c|c|c|}
\hline & $\mathbf{1}$ & $\mathbf{2}$ & $\mathbf{3}$ & $\mathbf{4}$ & $\mathbf{5}$ & $\mathbf{6}$ & $\mathbf{7}$ & $\mathbf{8}$ & $\mathbf{9}$ & $\mathbf{1 0}$ & $\mathbf{1 1}$ & $\mathbf{1 2}$ \\
\hline 1 & & $0.177^{*}$ & $0.162^{*}$ & $0.709^{* *}$ & 0.038 & $-0.220^{* *}$ & $0.590^{* *}$ & $0.480^{* *}$ & $0.428^{* *}$ & 0.000 & -0.139 & $-0.212^{* *}$ \\
\hline 2 & $0.177^{*}$ & & 0.018 & 0.152 & -0.023 & 0.021 & 0.077 & $0.199^{*}$ & 0.063 & 0.079 & -0.146 & $-0.186^{*}$ \\
\hline 3 & $0.162^{*}$ & 0.018 & & $0.209^{*}$ & 0.089 & $-0.462^{* *}$ & $0.257^{* *}$ & 0.068 & $0.329^{* *}$ & -0.012 & 0.097 & $-0.181^{*}$ \\
\hline 4 & $0.709^{* *}$ & 0.152 & $-0.209^{*}$ & & -0.005 & $-0.243^{* *}$ & $0.527^{* *}$ & $0.318^{* *}$ & $0.352^{* *}$ & -0.135 & -0.065 & $-0.218^{* *}$ \\
\hline 5 & 0.038 & -0.023 & 0.089 & -0.005 & & $-0.163^{*}$ & 0.036 & 0.131 & 0.133 & -0.124 & $-0.199^{*}$ & 0.099 \\
\hline 6 & $-0.220^{* *}$ & 0.021 & $-0.462^{* *}$ & $-0.243^{* *}$ & $-0.163^{*}$ & & $-0.688^{* *}$ & -0.079 & $-0.577^{* *}$ & $-0.179^{*}$ & 0.126 & -0.003 \\
\hline 7 & $0.590^{* *}$ & 0.077 & $0.257^{* *}$ & $0.527^{* *}$ & 0.036 & $-0.688^{* *}$ & & $0.180^{*}$ & $0.574^{* *}$ & 0.054 & -0.062 & $-0.168^{*}$ \\
\hline 8 & $0.480^{* *}$ & $0.199^{*}$ & 0.068 & $0.318^{* *}$ & 0.131 & -0.079 & $0.180^{*}$ & & $0.318^{* *}$ & 0.049 & $-0.181^{*}$ & -0.119 \\
\hline 9 & $0.428^{* *}$ & 0.063 & $0.329^{* *}$ & $0.352^{* *}$ & 0.133 & $-0.577^{* *}$ & $0.574^{* *}$ & $0.318^{* *}$ & & $0.232^{* *}$ & $-0.236^{* *}$ & 0.002 \\
\hline 10 & 0.000 & 0.079 & -0.012 & -0.135 & -0.124 & $-0.179^{*}$ & 0.054 & 0.049 & $0.232^{* *}$ & & $-0.188^{*}$ & $0.274^{* *}$ \\
\hline 11 & -0.139 & -0.146 & 0.097 & -0.065 & $-0.199^{*}$ & 0.126 & -0.062 & $-0.181^{*}$ & $-0.236^{* *}$ & $-0.188^{*}$ & & $-0.409^{* *}$ \\
\hline 12 & $-0.212^{* *}$ & $-0.186^{*}$ & $-0.181^{*}$ & $-0.218^{* *}$ & 0.099 & -0.003 & $-0.168^{*}$ & -0.119 & 0.002 & $0.274^{* *}$ & $-0.409^{* *}$ & \\
\hline
\end{tabular}

Note: $*$ Stands for significance at $5 \%, * *$ Stands for significance at $1 \%$. 
million USD) to 1,965 million PLN, with a mean (median) value of 57,372 million PLN (41,332 million USD). The descriptive statistics demonstrate that public banks in Poland bring a relatively high rate of return to their shareholder. ROE ranges from -31.41 to $30.60 \%$ with a mean (median) of $10.88 \%$ (11.78\%). Polish banks are highly levered; the mean (median) debt-to-assets ratio is $89.69 \%(90.27 \%)$.

Table 4 presents the Spearman correlations matrix between the independent variables, as well as with our self-constructed dependent variable - AQI. Consistent with our expectations, the correlations suggest that the quality of remuneration policy is positively correlated to board independence, frequency of remuneration committee meetings, CEO's annual remuneration and bank size. Of the independent variables, bank size is the most correlated one with other measures. The figures suggest that the threat of multicollinearity is limited.

\subsection{Tests of hypotheses}

We present the regression results in Table 5. Our results show positive and significant associations between remuneration policy quality and a number of corporate governance measures and control variables.

Table 5 shows the results of micro-panel regression. The dependent variable is the aggregate index of the quality of executive remuneration policy. Independent variables are governance measures: board size and independence, frequency of remuneration committee meetings, women's ratio on boards, pension funds' ownership, ownership concentration, regulations and identity of the dominant shareholder (dummies). There are several control variables representing economic determinants such as CEO's annual remuneration, bank size, ROE, leverage and investment opportunity.

Table 5 shows the results of pool, fixed effects and random effects models regression. The pool model refers to a model without distinction of the data heterogeneity over time or individual groups; the fixed within time effect model imposes individual group independent effects for each time entity; and the random time effects model takes into account the estimations of random effects, which are contained in errors of the model.

Interpretation of the dependencies between the quality of banks' executive remuneration policy and its determinants is performed on the basis of pool model 2. Selection of the model was dictated by the possibility of quantifying the impact of unobservable factors not included in the model, which are specific for a given period and determined the level of disclosure index. The Fisher and Breusche-Pagan robust tests confirm that including time or individual effects doesn't improve the explanatory power of the model.

Among the corporate governance measures, board size, frequency of remuneration committee meetings and pension funds' ownership are significant. According to the first hypothesis, larger supervisory boards are associated with a lower quality of remuneration policy. Each additional board member decreases the value of AIQ by 0.025 . As predicted in the third hypothesis, we find evidence that the higher the frequency of remuneration committee meetings, the higher is the quality of the executive remuneration policy of the bank. One more committee meeting a year increases the quality index by 0.08 on a 0.01 significance level. This positive impact of remuneration committee meetings is consistent with other studies (Laksman 2008; Conyon - Peck 1998). Remuneration committees in the Polish banks seem to be one of the most influential corporate governance institutional factors shaping efficient rewarding schemes. 
Table 5. The relationships between quality of banks' executive remuneration policy and its determinants

\begin{tabular}{|c|c|c|c|c|c|c|}
\hline & \multicolumn{2}{|c|}{ Pool model } & \multicolumn{2}{|c|}{ Fixed within time effect models } & \multicolumn{2}{|c|}{ Random time effects models } \\
\hline & Model 1 & Model 2 & Model 1 & Model 2 & Model 1 & Model 2 \\
\hline Board size & $\begin{array}{c}-0.027^{* *} \\
\mathrm{t}=-2.447\end{array}$ & $\begin{array}{c}-0.025^{* *} \\
\mathrm{t}=-2.334\end{array}$ & $\begin{array}{c}-0.027^{* *} \\
\mathrm{t}=-2.286\end{array}$ & $\begin{array}{c}-0.025^{* *} \\
\mathrm{t}=-2.306\end{array}$ & $\begin{array}{c}-0.027^{* *} \\
\mathrm{t}=-2.402\end{array}$ & $\begin{array}{c}-0.025^{* *} \\
\mathrm{t}=-2.337\end{array}$ \\
\hline Board independence & $\begin{array}{c}0.0002 \\
t=0.131\end{array}$ & & $\begin{array}{c}-0.0001 \\
t=-0.093\end{array}$ & & $\begin{array}{c}0.00002 \\
t=0.010\end{array}$ & \\
\hline $\begin{array}{l}\text { Frequency of remuneration } \\
\text { committee meetings }\end{array}$ & $\begin{array}{c}0.080^{* * *} \\
\mathrm{t}=6.742\end{array}$ & $\begin{array}{c}0.077^{* * *} \\
\mathrm{t}=6.672\end{array}$ & $\begin{array}{l}0.083^{* * *} \\
t=6.679\end{array}$ & $\begin{array}{c}0.082^{* * *} \\
t=6.781\end{array}$ & $\begin{array}{c}0.081^{* * *} \\
t=6.835\end{array}$ & $\begin{array}{c}0.076^{* * *} \\
t=6.622\end{array}$ \\
\hline Women on board & $\begin{array}{c}-0.001 \\
\mathrm{t}=-0.702\end{array}$ & & $\begin{array}{c}-0.001 \\
t=-0.532\end{array}$ & & $\begin{array}{c}-0.001 \\
t=-0.620\end{array}$ & \\
\hline Pension funds ownership & $\begin{array}{c}0.012^{* *} \\
t=2.293\end{array}$ & $\begin{array}{l}0.013^{* * *} \\
t=3.072\end{array}$ & $\begin{array}{c}0.012^{* *} \\
t=2.173\end{array}$ & $\begin{array}{c}0.013^{* * *} \\
t=3.072\end{array}$ & $\begin{array}{c}0.012^{* *} \\
t=2.271\end{array}$ & $\begin{array}{c}0.012^{* * *} \\
t=2.996\end{array}$ \\
\hline Northern Europe & $\begin{array}{c}0.121^{* *} \\
t=1.994\end{array}$ & $\begin{array}{c}0.117^{* *} \\
t=2.119\end{array}$ & $\begin{array}{c}0.120^{*} \\
t=1.914\end{array}$ & $\begin{array}{c}0.117^{* *} \\
t=2.119\end{array}$ & $\begin{array}{c}0.121^{* *} \\
t=1.989\end{array}$ & $\begin{array}{c}0.117^{* *} \\
t=2.134\end{array}$ \\
\hline Poland & $\begin{array}{c}-0.322^{* * *} \\
\mathrm{t}=-3.970\end{array}$ & $\begin{array}{c}-0.312^{* * *} \\
\mathrm{t}=-4.439\end{array}$ & $\begin{array}{c}-0.319^{* * *} \\
\mathrm{t}=-3.746\end{array}$ & $\begin{array}{c}-0.312^{* * *} \\
\mathrm{t}=-4.439\end{array}$ & $\begin{array}{c}-0.321^{* * *} \\
\mathrm{t}=-3.936\end{array}$ & $\begin{array}{c}-0.324^{* * *} \\
\mathrm{t}=-4.695\end{array}$ \\
\hline US-UK-Ireland & $\begin{array}{c}0.159^{* *} \\
\mathrm{t}=1.999\end{array}$ & $\begin{array}{c}0.149^{* *} \\
t=2.207\end{array}$ & $\begin{array}{c}0.160^{*} \\
t=1.935\end{array}$ & $\begin{array}{c}0.149^{* *} \\
t=2.207\end{array}$ & $\begin{array}{c}0.160^{* *} \\
t=2.007\end{array}$ & $\begin{array}{c}0.142^{* *} \\
\mathrm{t}=2.121\end{array}$ \\
\hline Regulations & $\begin{array}{l}0.322^{* * *} \\
t=5.010\end{array}$ & $\begin{array}{c}0.282^{* * *} \\
t=5.380\end{array}$ & & & $\begin{array}{l}0.315 \\
\mathrm{t}=3.811^{* * *}\end{array}$ & $\begin{array}{l}0.285 \mathrm{t}= \\
5.706^{* * *}\end{array}$ \\
\hline CEO's annual remuneration & $\begin{array}{l}0.00004^{* * *} \\
t=2.913\end{array}$ & $\begin{array}{l}0.00004^{* * *} \\
t=2.886\end{array}$ & $\begin{array}{l}0.00004^{* * *} \\
t=2.705\end{array}$ & $\begin{array}{l}0.00004^{* * *} \\
t=2.842\end{array}$ & $\begin{array}{l}0.00004^{* * *} \\
t=2.850\end{array}$ & $\begin{array}{l}0.00004^{* * *} \\
\mathrm{t}=2.883\end{array}$ \\
\hline Bank size & $\begin{array}{l}0.092^{* * *} \\
\mathrm{t}=2.785\end{array}$ & $\begin{array}{l}0.114^{* * *} \\
\mathrm{t}=4.047\end{array}$ & $\begin{array}{l}0.093^{* * *} \\
t=2.631\end{array}$ & $\begin{array}{c}0.113^{* * *} \\
t=3.893\end{array}$ & $\begin{array}{l}0.092^{* * *} \\
t=2.756\end{array}$ & $\begin{array}{l}0.115^{* * *} \\
t=4.053\end{array}$ \\
\hline $\mathrm{ROE}_{\mathrm{t}}$ & $\begin{array}{c}0.007^{* *} \\
t=2.079\end{array}$ & & $\begin{array}{c}0.006 \\
t=1.508\end{array}$ & & $\begin{array}{c}0.006^{*} \\
t=1.824\end{array}$ & \\
\hline
\end{tabular}


Table 5. Continued

\begin{tabular}{|c|c|c|c|c|c|c|}
\hline & \multicolumn{2}{|c|}{ Pool model } & \multicolumn{2}{|c|}{ Fixed within time effect models } & \multicolumn{2}{|c|}{ Random time effects models } \\
\hline & Model 1 & Model 2 & Model 1 & Model 2 & Model 1 & Model 2 \\
\hline Leverage & $\begin{array}{c}-0.0001 \mathrm{t}= \\
-0.009\end{array}$ & & $\begin{array}{l}0.0001 \\
t=0.008\end{array}$ & & $\begin{array}{c}0.0001 \\
t=0.008\end{array}$ & \\
\hline Investment opportunity & $\begin{array}{c}-0.066 \mathrm{t}= \\
-0.352\end{array}$ & & $\begin{array}{l}-0.065 \mathrm{t}= \\
-0.314\end{array}$ & & $\begin{array}{c}-0.064 \mathrm{t}= \\
-0.330\end{array}$ & \\
\hline Constant & $\begin{array}{c}-0.917 \mathrm{t}= \\
-0.700\end{array}$ & $\begin{array}{l}-1.473^{* * *} \\
t=-3.151\end{array}$ & & & $\begin{array}{c}-1.077 \mathrm{t}= \\
-0.789\end{array}$ & $\begin{array}{l}-1.476^{* * *} \\
\mathrm{t}=-3.155\end{array}$ \\
\hline $\mathrm{R}^{2}$ & 0.783 & 0.774 & 0.690 & 0.682 & 0.739 & 0.784 \\
\hline Adj. $R^{2}$ & 0.699 & 0.722 & 0.575 & 0.595 & 0.660 & 0.732 \\
\hline F-statistic & $\begin{array}{c}32.167^{* * *} \\
\text { (df }=15 ; 134)\end{array}$ & $\begin{array}{c}53.224^{* * *} \\
(\mathrm{df}=9 ; 140)\end{array}$ & $\begin{array}{c}19.831^{* * *} \\
(\mathrm{df}=14 ; 125)\end{array}$ & \begin{tabular}{|c|}
$35.096^{* * *}$ \\
(df $=8 ; 131)$
\end{tabular} & $\begin{array}{c}25.332^{* * *} \\
(\mathrm{df}=15 ; 134)\end{array}$ & $\begin{array}{c}56.452^{* * *} \\
(\mathrm{df}=9 ; 140)\end{array}$ \\
\hline Observations & \multicolumn{6}{|c|}{150} \\
\hline \multirow[t]{2}{*}{ Test $F$ for within time effects } & \multicolumn{3}{|c|}{ F_stat. } & \multicolumn{3}{|c|}{ F_p.val } \\
\hline & \multicolumn{3}{|c|}{0.6897413} & \multicolumn{3}{|c|}{$7.171653 e-01$} \\
\hline \multirow{2}{*}{$\begin{array}{l}\text { Breusch-Pagan test for time random } \\
\text { effects }\end{array}$} & \multicolumn{3}{|c|}{ BP_stat. } & \multicolumn{3}{|c|}{ BP_p.val } \\
\hline & \multicolumn{3}{|c|}{$3.284390 \mathrm{e}-04$} & \multicolumn{3}{|c|}{$9.855408 \mathrm{e}-01$} \\
\hline \multirow[t]{2}{*}{ Hausman test for time effects model } & \multicolumn{3}{|c|}{ H_stat. } & \multicolumn{3}{|c|}{ H_p.val } \\
\hline & \multicolumn{3}{|c|}{4.710093} & \multicolumn{3}{|c|}{ 7.880646e-01 } \\
\hline
\end{tabular}

Note: *Stands for significance at $10 \%, * *$ Stands for significance at $5 \%,{ }^{* *}$ Stands for significance at $1 \%$. 
Furthermore, the result suggests that the second institutional factor positively associated with compensation policy quality is pension funds' ownership. A one per cent greater involvement of pension funds in the bank's equity stake increases the AQI by 0.013 .

Our analysis confirms that board independence and ownership concentration have a positive but non-significant impact on the quality of remuneration policy. The most important role of independent board members in the Polish public banks with highly concentrated ownership structure is to protect the interests of minority shareholders. In this context, an efficient compensation policy does not seem to be a priority in the tasks performed by such members. Considering the impact of the ownership concentration, one should expect that within block holding companies, the majority shareholders have the ability and motivation to wield sufficient power to control management, implementing high quality incentive system. However, in the sample banks we can observe relatively homogenous ownership structures - mean and standard deviation of the ownership concentration equal 71.7 and $17.9 \%$ respectively. Due to the small ownership diversification of the sample, ownership concentration may not have a significant impact on the pay-setting process.

The coefficient for the ratio of women on the board is negative and non-significant. It is consistent with the previous Polish study reporting that females on the board fail to monitor executives effectively (Slomka-Golebiowska - Urbanek 2016). Since women are underrepresented (on average 11\%) they feel to be loyal to the large shareholder who sets the main assumptions of executive compensation policy.

We further investigate how the compensation quality depends on the country of origin of a dominant shareholder. Banks which are controlled by the US-UK-Ireland financial institutions have an aggregate quality index nearly $20 \%$ higher than other banks. We obtain a similar outcome for the Northern European investors (15\%). These results may indicate that the strategic investors transfer their high standards of compensation policy to the subsidiaries. This result is consistent with the findings of Fernandes et al. (2013), which document the convergence of CEO pay practices internationally. On the other hand, the quality of compensation policy in banks with the Polish dominant shareholders is worse by about $40 \%$. This result can be interpreted as a consequence of the state ownership of and control over domestically-owned banks, which leads to a relatively lower level of efficiency. Liang et al. (2015) document such political determinants of executive compensation as an alternative mechanism to market forces.

We also find strong evidence that the quality is higher for observations occurring after 2012, the year new regulations were imposed on the banking sector. The compensation quality index increased nearly $30 \%$, because the Polish banks had to implement the new requirements in their compensation procedures based on the CRD III Directive of the European Parliament.

It is apparent that bank size and CEO's annual remuneration are significantly positively correlated with the dependent variable at a 0.01 significance level. Capital market institutions, regulators and public opinion expect larger banks to increase the transparency of their compensation policy, which makes them implement more efficient pay-setting procedures. Our results are in agreement with the findings of Ben-Amara et al. (2014) that larger firms have more resources and expertise to prepare more transparent information about compensation practices. 
Also, the above-average level of CEO's compensation requires its legitimization, which might take the form of a higher level of compensation policy quality.

\section{CONCLUSIONS}

Our study examined the relationship between the quality of executive remuneration policy measured by the aggregate quality index and corporate governance standards at the publiclytraded banks in Poland. We documented three main findings.

The first one has significant implications for the regulators. Our results indicate that the effective implementation of sound corporate governance practices by the Polish financial institutions should be rooted in the legislative system in the form of obligatory normative acts. There are two main groups of factors that might prompt banks to implement efficient pay contracts. The first is optional and is associated with the corporate governance codes, based generally on a "comply or explain" mechanism and also on a bank's bottom-up need to prove to shareholders, stakeholders, capital markets institutions and other parties that its compensation policy is in accordance with the socially accepted standards of professionalism. The second group is due to obligatory legal regulations which require financial institutions to establish formal procedures for setting remuneration. Taking into account the causes and course of the recent financial crisis, it seems that informal voluntary institutions should have had a significant impact on the propensity of the financial sector entities to introduce high quality executive compensation policies in the period after the outbreak of the crisis. Ineffective remuneration policy has been widely recognized as one of the main reasons which encouraged bank executives to engage in high-risk business ventures, which in effect led to the instability of the financial markets. Our results reveal that the Polish banks did not use such methods of communication with capital markets, inter alia with respect to efficient executive remuneration policy, to restore confidence in the banking sector. Significant improvements in the quality of remuneration policy have only been observed since 2012, after the transposition of the European Community requirements into the Polish national law. This refers, first of all, to the variable remuneration procedures. However, it should also be emphasized that the level of quality still reaches only approximately $40-50 \%$ of the procedures required by law. This may indicate the inconsistency of these regulations and difficulty in their unambiguous interpretation. It may also show the weakness of the institutions responsible for the supervision of financial markets in terms of enforcement of the regulations.

Secondly, consistent with other studies on the approach to remuneration, we find a positive and statistically significant relationship between corporate governance measures and the quality of remuneration policy. In particular, the study shows the significant role of two institutional factors positively determining the efficiency of incentive contracts: remuneration committees and institutional ownership. The frequency of remuneration committee meetings is positively associated with the quality of executive remuneration policy. In addition, our study provides evidence that a larger stake in the hands of private pension funds, which are the most significant minority shareholders in the Polish public banks, also increases the remuneration policy quality. In accordance with other studies, we find that larger supervisory boards are associated with a lower quality of remuneration policy. We also find that the banks controlled by foreign 
corporations, especially the US-UK-Ireland financial institutions, have a significantly more effective compensation policy than the banks controlled by domestic investors. Consistent with the previous studies we also documented that large banks and banks paying higher compensation to their CEOs have more efficient executive remuneration policies.

\section{REFERENCES}

Adams, R. - Ferreira, D. (2009): Women in the Boardroom and Their Impact of Governance and Performance. Journal of Financial Economics, 94 (2): 291-309.

Ang, J. - Lauterbach, B. - Schreiber, B. (2002): Pay at the Executive Suite: How do U.S. Banks Compensate their Top Management Teams. Journal of Banking - Finance, 26 (6): 1143-1163.

Baker, G. P. - Jensen, M. C. - Murphy, K. J. (1988): Compensation and Incentives: Practice vs. Theory. Journal of Finance, 63(3): 593-616.

Balachandran, S. - Kogut, B. - Harnal, H. (2010): The Probability of Default, Excessive Risk, and Executive Compensation: A Study of Financial Services Firms from 1995 to 2008. Columbia Business School Research Paper Series.

Barro, J. R. - Barro, R. (1990): Pay, Performance, and Turnover of Bank CEOs. Journal of Labor Economics, 8(4): 448-481.

Bebchuk, L. - Cohen, A. - Spamann, H. (2010): The Wages of Failure: Executive Compensation at Bear Stearns and Lehman 2000-2008. Yale Journal on Regulation, 27: 257-282.

Bebchuk, L. A. - Fried, J. M. (2003): Executive Compensation as an Agency Problem. Journal of Economic Perspectives, 17(3): 71-92.

Ben-Amar, W. - Smaili, N. - Mandzila, E. (2014): Corporate Social Responsibility and the Quality of Executive Compensation Disclosures. The Journal of Applied Business Research, 30(2): 625632.

Ben-Amar, W. - Zeghal, D. (2011): Board of Directors' Independence and Executive Compensation Disclosure Transparency. Journal of Applied Accounting Research, 12(1): 43-60.

Bender, R. - Porter, B. (2001): A Process Model of Directors Remuneration. Paper presented at the 24th Annual Congress of the European Accounting Association, Athens.

Bhagat, S. - Bolton, B. (2013): Bank Executive Compensation and Capital Requirements Reform, http://ssrn. com/abstract $=1781318$. Accessed 5 January 2017.

Burghof, H. P. - Hofman, C. (2000): Executives' Compensation of European Banks - Disclosure, Sensitivity, and their Impact on Bank Performance. Munich Business Research, 2000-01.

Cadbury, A. (2002): Corporate Governance and Chairmanship. A Personal View. Oxford: Oxford University Press.

Chung, H. - Judge, W. Q. - Li, Y-H. (2015): Voluntary Disclosure, Excess Executive Compensation, and Firm Value. Journal of Corporate Finance, 32: 64-90.

Clarkson, P. - Ami Lammerts, B. - Walker, J. (2005): CEO Remuneration Disclosure Quality: An Australian Perspective. University of Queensland Business School.

Committee of European Banking Supervisors (2009): High-level Principles of Remuneration Policy.

Conyon, M. J. - Peck, S. (1998): Board Control, Remuneration Committees, and Top Management Compensation. Academy of Management Journal, 41(2): 146-157. 
Coulton, J. - James, C. - Taylor, S. (2001): The Transparency of CEO Compensation Disclosures: Does Corporate Governance Matter? Sydney: University of Technology.

Cunat, V. - Guadalupe, M. (2009): Executive Compensation and Competition in the Banking and Financial Sector. Journal of Banking - Finance, 33(3): 495-504.

Demsetz, R. - Sainderberg, M. (1999): Looking Beyond the CEO: Executive Compensation at Banks. Federal Reserve Bank of New York, No. 68.

DeYoung, R. - Peng, E. - Yan, M. (2013): Executive Compensation and Business Policy Choices at U.S. Commercial Banks. Journal of Financial and Quantitative Analysis, 48(1): 165-196.

Doucouliagos, H. - Haman, J. - Askary, S. (2007): Director's Remuneration and Performance in Australian Banking. Corporate Governance, 15(6): 1363-1383.

Eng, L. L. - Mak, Y. T. (2003): Corporate Governance and Voluntary Disclosure. Journal of Accounting and Public Policy, 22(4): 325-345.

European Banking Authority (2015): Guidelines on Sound Remuneration Policies under Articles 74(3) and 75(2) of Directive 2013/36/EU and Disclosures under Article 450 of Regulation (EU), No. 575/2013.

European Parliament (2013): Directive 2013/36/EU of the European Parliament and of the Council of 26 June 2013 on Access to the Activity of Credit Institutions and the Prudential Supervision of Credit Institutions and Investment Firms, Amending Directive 2002/87/EC and Repealing Directives 2006/48/ EC and 2006/49/EC.

Fahlenbrach, R. - Stulz, R. (2009): Bank CEO Incentives and the Credit Crisis. NBER Working Paper Series, No. 15212.

Fernandes, N. - Ferreira, M. A. - Matos, P. - Murphy, K. J. (2013): Are US CEOs Paid More? New International Evidence. Review of Financial Studies, 26(2): 323-367.

Ferrarini, G. - Moloney, N. - Ungureanu, M. C. (2010): Executive Rem-uneration in Crisis: A Critical Assessment of Reforms in Europe. Journal of Corporate Law Studies, 10(1): 73-118.

Freeman, R. E. (1984): Strategic Management: A Stakeholder Approach. London: Pitman.

Gomez-Mejia, L. - Wiseman, R. M. (1997): Reframing Executive Compensation: An Assessment and Outlook. Journal of Management, 23(3): 291-374.

Gordon, J. N. (2006): Executive Compensation: If there's a Problem, What's the Remedy? The Case for Compensation Disclosure and Analysis. Journal of Corporation Law, Summer 102-130.

Greene, W. (2003): Econometrics Analysis. New Jersey: Prentice Hall.

Gregg, P. - Jewell, S. - Tonks, I. (2012): Executive Pay and Performance: Did Bankers' Bonuses Cause the Crisis? International Review of Finance, 12(1): 89-122.

Hearit, K. M. (1995): "Mistakes Were Made": Organizations, Apologia, and Crises of Social Legitimacy. Communication Studies, 46(1-2): 1-17.

Hubbard, R. G. - Palia, D. (1995): Executive Pay and Performance. Evidence from the U.S. Banking Industry. Journal of Financial Economics, 39: 105-130.

Jensen, M. C. - Murphy, K. J. (1990): CEO Incentives - It's Not How Much You Pay, But How. Harvard Business Review, May-June: 138-157.

John, K. - Yiming, Q. (2003): Incentive Features in CEO Compensation in the Banking Industry. Economic Policy Review, April: 109-120.

Katmon, N. - Al Farooque, O. (2017): Exploring the Impact of Internal Corporate Governance on the Relation Between Disclosure Quality and Earnings Management in the UK Listed Companies. Journal of Business Ethics, 142: 345-367.

Kerr, J. - Betis, R. A. (1987): Boards of Directors, Top Management Compensation, and Shareholders Returns. Academy of Management Journal, 30(4): 645-664. 
Kim, Y. - Park, M. S. - Wier, B. (2012): Is Earnings Quality Associated with Corporate Social Responsibility? The Accounting Review, 87(3): 761-796.

Laksamana, I. (2008): Corporate Board Governance and Voluntary Disclosure of Executive Compensation Practice. Contemporary Accounting Research, 25: 1147-1182.

Lang, M. - Lundholm, R. (1993): Cross-Sectional Determinants of Analyst Ratings of Corporate Disclosures. Journal of Accounting Research, 31: 246-271.

Liang, H. - Renneboog, L. - Sun, S. L. (2015): The Political Determinants of Executive Compensation: Evidence from an Emerging Economy. Emerging Markets Review, 25: 69-91.

Loukil, N. - Yousfi, O. (2016): Does Gender Diversity on Corporate Boards Increase Risk- Taking? Canadian Journal of Administrative Sciences, 33: 66-81.

Murphy, K. J. (2011): The Politics of Pay: A Legislative History of Executive Compensation. Marshall School of Business Working Paper, No. FBE 01.11.

Murphy, K. J. (2012): Pay, Politics and the Financial Crisis. https://pdfs.semanticscholar.org/4ec9/ b5703fe80011442ab23a17bd9a2333cdef27.pdf. Accessed 15 December 2016.

Muslu, V. (2007): The Effect of Insiders on Compensation Disclosure and Incentive Compensation: Evidence from Europe. University of Texas Working Paper, Richardson, TX.

Passador, M. L. (2017): Corporate Governance Models: the Japanese Experience in Context. DePaul Business - Commercial Law Journal, 15: 25-53.

Redmond, W. R. (2004): On Institutional Rationality. Journal of Economic Issues, 38(1): 173-188.

Shleifer, A. - Vishny, R. W. (1996): A Survey of Corporate Governance. National Bureau of Economic Research Working Paper, No. 5554, Cambridge, MA.

Słomka-Gołębiewska, A. - Urbanek, P. (2016): Corporate Boards, Large Block holders and Executive Compensation in Banks: Evidence from Poland. Emerging Markets Review, 28: 203-220.

Suchman, M. C. (1995): Managing Legitimacy: Strategic and Institutional Approaches. Academy of Management Journal, 20(3): 571-611.

Tosi, H. I. - Gomez-Mejia, L. R. (1989): The Decoupling of CEO Pay and Performance: an Agency Theory Perspective. Administrative Science Quarterly, 34: 169-189.

Tosi, H. L. - Werner, S. - Katz, J. P. - Gomez-Mejia, L. R. (2000): How Much Does Performance Matter? A Meta-analysis of CEO Pay Studies. Journal of Management, 26(2): 301-339.

Vallascas, F. - Hangendorff, J. (2013): CEO Remuneration and Bank Default Risk: Evidence from the U.S. and Europe. Financial Markets, Institutions - Instruments, 22(2): 47-89.

Vives, X. (2000): Corporate Governance. Theoretical and Empirical Perspectives. Cambridge University Press. 


\section{APPENDIX 1. EXECUTIVE REMUNERATION POLICY QUALITY VARIABLES USED FOR SUB-INDICES}

\begin{tabular}{|c|c|}
\hline Variable compensation sub-index & \\
\hline $\begin{array}{l}\text { 1. Not paying out or reducing current payments } \\
\text { (malus) in justified cases. }\end{array}$ & $0-1$ \\
\hline $\begin{array}{l}\text { 2. Clawing back bonuses (clawbacks) in justified } \\
\text { cases. }\end{array}$ & $0-1$ \\
\hline $\begin{array}{l}\text { 3. Deferral period of the variable components of } \\
\text { bonus }\end{array}$ & $\begin{array}{c}\text { less than } 3 \text { years- } 03 \text { years }-14 \text { years- } 2 \text { more than } 5 \\
\text { years- } 3\end{array}$ \\
\hline 4. Share of deferral pay in the variable components & 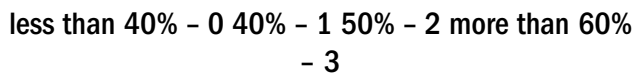 \\
\hline $\begin{array}{l}\text { 5. At least } 60 \text { per cent of variable pay of the most } \\
\text { senior executives such as CEO or CFO deferred }\end{array}$ & $0-1$ \\
\hline $\begin{array}{l}\text { 6. Criteria for performance evaluation of the } \\
\text { entitlement to variable components of executive } \\
\text { compensation }\end{array}$ & $\begin{array}{l}\text { none - } 0 \text { basic financial criteria - } 1 \text { advanced criteria } \\
-2\end{array}$ \\
\hline $\begin{array}{l}\text { 7. Non-financial criteria for performance evaluation of } \\
\text { the entitlement to variable components of executive }\end{array}$ & $0-1$ \\
\hline $\begin{array}{l}\text { 8. Assigning weighs for financial and non-financial } \\
\text { performance criteria }\end{array}$ & $0-1$ \\
\hline $\begin{array}{l}\text { 9. Using stress tests in order to align the executive } \\
\text { remuneration with bank's risk exposure and } \\
\text { financial results. }\end{array}$ & $0-1$ \\
\hline $\begin{array}{l}\text { 10. Share of variable component is larger than } 50 \% \text { of } \\
\text { total executive pay }\end{array}$ & $0-1$ \\
\hline $\begin{array}{l}\text { 11. Variable component tied to the business units' } \\
\text { and the bank's performance }\end{array}$ & $0-1$ \\
\hline $\begin{array}{l}\text { 12. At least } 50 \text { per cent of variable compensation } \\
\text { based on shares }\end{array}$ & $0-1$ \\
\hline \multicolumn{2}{|l|}{ Remuneration committee sub-index } \\
\hline 1. Remuneration committee in place & $0-1$ \\
\hline $\begin{array}{l}\text { 2. Share of the independent board members in the } \\
\text { remuneration committee }\end{array}$ & $\begin{array}{c}\text { less than } 25 \%-025-50 \%-151-75 \%-2 \text { more } \\
\text { than } 76 \%-3\end{array}$ \\
\hline $\begin{array}{l}\text { 3. Chairman of the remuneration committee is an } \\
\text { independent board member }\end{array}$ & $0-1$ \\
\hline $\begin{array}{l}\text { 4. Members of the remuneration committee sit on } \\
\text { boards of other public companies }\end{array}$ & $0-1$ \\
\hline
\end{tabular}




\section{Continued}

\begin{tabular}{|c|c|}
\hline Variable compensation sub-index & \\
\hline $\begin{array}{l}\text { 5. Bye-laws of a remuneration committee or in any } \\
\text { other internal regulation the procedures and } \\
\text { process of designing executive compensation } \\
\text { package are described }\end{array}$ & $0-1$ \\
\hline $\begin{array}{l}\text { 6. Board comments on the executive remuneration } \\
\text { policy in their annual statement. }\end{array}$ & $0-1$ \\
\hline $\begin{array}{l}\text { 7. Remuneration committee members are competent } \\
\text { and experienced in setting remuneration policy, }\end{array}$ & $0-1$ \\
\hline $\begin{array}{l}\text { 8. Remuneration committee is closely cooperating } \\
\text { with the risk committee in the evaluation of the } \\
\text { incentives created by the compensation system. }\end{array}$ & $0-1$ \\
\hline 9. Frequency of remuneration committee meetings & $\begin{array}{c}\text { none - } 0 \text { once per annum - } 1 \text { once per half a year - } \\
2 \text { quarterly and more }-3\end{array}$ \\
\hline \multicolumn{2}{|l|}{ Long-term incentive programs sub-index } \\
\hline 1. Bank uses the long-term incentive programs LTIP & $0-1$ \\
\hline 2. LTIP based on bank's shares & $0-1$ \\
\hline 3. Approval of LTIP by the AGM & $0-1$ \\
\hline $\begin{array}{l}\text { 4. The scope of LTIP - which groups of employees are } \\
\text { covered by the program }\end{array}$ & $\begin{array}{c}\text { none - } 0 \text { only management board - } 1 \text { management } \\
\text { board and other managers - } 2 \text { management board, } \\
\text { other managers and other employees - } 3\end{array}$ \\
\hline 5. Vesting period & $\begin{array}{c}\text { less than } 3 \text { years }-03 \text { years }-14 \text { years- } 2 \text { more than } 5 \\
\text { years- } 3\end{array}$ \\
\hline $\begin{array}{l}\text { 6. Conditions to fulfil for vesting include the analysis } \\
\text { of the bank's performance in comparison to peer } \\
\text { group }\end{array}$ & $0-1$ \\
\hline $\begin{array}{l}\text { 7. Conditions to fulfil for vesting include criteria for } \\
\text { individual performance evaluation }\end{array}$ & $0-1$ \\
\hline 8. Discount the exercise price of stock options & $0-1$ \\
\hline 9. Indexed stock options & $0-1$ \\
\hline $\begin{array}{l}\text { 10. Other conditions than being employed in the bank } \\
\text { to fulfil for vesting }\end{array}$ & $0-1$ \\
\hline
\end{tabular}

